\title{
Prostaglandin D Synthase in the Prenatal Ovine Brain and Effects of Its Inhibition with Selenium Chloride on Fetal Sleep/Wake Activity In Utero
}

\author{
Brenda Lee, Jonathan J. Hirst, and David W. Walker \\ Department of Physiology, Monash University, Clayton, Melbourne, Victoria, Australia, 3800
}

It has been proposed that prostaglandin (PG) $D_{2}$ induces physiological sleep in mammals by acting on sleep centers located in the anterior hypothalamus. In fetal sheep, definitive rapideye-movement and non-rapid-eye-movement sleep states appear at $\sim 125 \mathrm{~d}$ gestation (term is $\sim 147 \mathrm{~d}$ ). In adult animals, PGD synthase (PGDS) (functionally and structurally homologous to $\beta$-trace protein) is secreted into CSF with a circadian pattern, with the highest concentrations present during sleep. In this study we show that PGDS/ $\beta$-trace protein is present in fetal sheep CSF at 125 and $135 \mathrm{~d}$ gestation but not at $90 \mathrm{~d}$ gestation. $\mathrm{SeCl}_{4}$, a specific inhibitor of PGDS, was given to unanesthetized fetal sheep (130-140 d gestation) by intracerebroventricular infusion at a dose of 25, 100, 500, or 1000 $\mathrm{pmol} / \mathrm{min}$ for $4 \mathrm{hr}$. Artificial CSF was infused in control experiments. Arousal behavior, defined as the presence of nuchal muscle electromyogram activity, electro-ocular activity, and breathing movements during low-amplitude electrocortical activity, increased from $3.8 \pm 1 \mathrm{~min} / \mathrm{hr}$ to $6.6 \pm 0.5$ and $7.0 \pm 0.3$ $\mathrm{min} / \mathrm{hr}$ at doses of 100 and $500 \mathrm{pmol} / \mathrm{min}$, respectively $(p<$ 0.05). $\mathrm{SeCl}_{4}$ at 25 and $1000 \mathrm{pmol} / \mathrm{min}$ had no significant effect on arousal activity. Infusion of $\mathrm{PGD}_{2}$ at $500 \mathrm{pmol} / \mathrm{min}$ intracerebroventricularly for $4 \mathrm{hr}$ decreased the incidence of arousal from $3.8 \pm 0.5 \mathrm{~min} / \mathrm{hr}$ to $0.7 \pm 0.3 \mathrm{~min} / \mathrm{hr}(p<0.05)$. When 500 $\mathrm{pmol} / \mathrm{min} \mathrm{PGD}_{2}$ was infused immediately after a $4 \mathrm{hr}$ infusion of $\mathrm{SeCl}_{4}(500 \mathrm{pmol} / \mathrm{min})$, the $\mathrm{SeCl}_{4}$-induced increase in arousal behavior was abolished. Together, the presence of PGDS $/ \beta$ trace protein in fetal CSF in late gestation and the effects of $\mathrm{SeCl}_{4}$ in increasing the incidence of arousal-like behavior suggest that $P G D_{2}$ has a role in the induction and maintenance of prenatal sleep.

Key words: fetus; sleep/wake; arousal; prostaglandin D synthase; $\beta$-trace protein; selenium chloride
In species with long gestations, considerable brain development occurs before birth; EEG and locomotor activities suggestive of sleep become evident by late gestation (Dawes et al., 1972; Ruckebusch et al., 1977; Clewlow et al., 1983; Szeto, 1992). In the sheep fetus, rapid-eye-movement (REM) and non-rapid-eye-movement (NREM) sleep, defined by the coordinated and regular changes in the electrocorticogram (ECoG), postural muscle electromyogram (EMG), electro-oculogram (EOG) activity, and episodes of breathing movements, are established by $\sim 125 \mathrm{~d}$ (term $\sim 147 \mathrm{~d}$ ) gestation (Clewlow et al., 1983). These REM- and NREM-like episodes together account for $\sim 95 \%$ of the total time (Dawes et al., 1972; Szeto and Hinman, 1985). The remaining time is occupied by brief periods identified as fetal arousal or wakefulness and characterized, as in the adult, by episodes of low-amplitude ECoG activity occurring simultaneously with EOG and nuchal muscle activities and augmented breathing movements (Szeto, 1992; Crossley et al., 1997; Nicol et al., 1998, 2001).

It is not known why the propensity to sleep is so high in fetal life. The placenta appears to have an influence over fetal CNS activity (Adamson et al., 1987), arising perhaps from the lowoxygen environment that results from the high oxidative metabolism of the placenta, or because somnogenic substances, espe-

\footnotetext{
Received Oct. 4, 2001; revised March 12, 2002; accepted March 29, 2002.

This work was supported by grants from the National Health and Medical Research Council of Australia to D.W.W. and J.J.H. B.L. was an Australian Postgraduate Award scholar. We thank Alex Satragno for help with the animal surgery. Correspondence should be addressed to Dr. David Walker, Department of Physiology, Monash University, Wellington Road, Clayton, Melbourne, Victoria, Australia, 3800. E-mail: david.walker@med.monash.edu.au.

Copyright (ㄷ) 2002 Society for Neuroscience $0270-6474 / 02 / 225679-08 \$ 15.00 / 0$
}

cially neuroactive metabolites of progesterone, are released into fetal blood. Suprapontine control of fetal sleep was suggested by the observation that collicular transection disrupted the normal pattern of REM and NREM episodes (Dawes et al., 1983). However, little is known of the higher centers that might control the activity of the brainstem reticular network in the fetus and lead to the high incidence of sleep and low incidence of wakefulness in utero.

The anterior hypothalamus plays an essential role in sleep regulation (Sherin et al., 1996). It has been suggested that sleep induction occurs when prostaglandin (PG) $\mathrm{D}_{2}$ activates GABAergic neurons in the ventrolateral preoptic (VLPO) region, which then inhibits histaminergic neurons in the posterior hypothalamus (Scammell et al., 1998). Extensive evidence suggests that $\mathrm{PGD}_{2}$, formed from $\mathrm{PGH}_{2}$ by the enzyme prostaglandin D synthase (PGDS), acts to induce physiological sleep (Hayaishi et al., 1993; Matsumura et al., 1994; Urade and Hayaishi, 1999; Hayaishi, 2000). PGDS has structural and functional homology to $\beta$-trace protein, a major constituent of CSF in humans and other species (Hoffman et al., 1993) with enzymatic properties similar to those of brain PGDS (Watanabe et al., 1994). PGDS/ $\beta$-trace mRNA is found predominantly in choroid plexus and leptomeningeal cells (Urade et al., 1993, 1995; Hoffman et al., 1996; Ohe et al., 1996), and the protein is secreted into CSF. PGD 2 concentrations in CSF exhibit a circadian pattern (Pandley et al., 1995) and increase in CSF during sleep in the adult (Ram et al., 1997).

The question arises as to whether $\mathrm{PGD}_{2}$ is an endogenous sleep substance in the fetus, as it is in the adult. This study was designed to investigate whether $\mathrm{PGD}_{2}$ is involved in the maintenance of fetal sleep, first by determining whether PGDS was present in the 
CSF of fetal sheep and whether changes of content occurred in gestation around the time that sleep states first become evident; and second by making use of the observation that inorganic selenium compounds inhibit PGDS activity (Islam et al., 1991; Matsumura et al., 1991). $\mathrm{SeCl}_{4}$ was inf used into a lateral ventricle of fetal sheep in utero while recording sleep states, postural muscle activity, and breathing movements. Selenium compounds are specific and reversible inhibitors of brain-type PGDS because of their interaction with the cysteine- 65 residue within the hydrophobic pocket of the enzyme, a structural feature of PGDS not shared with other members of the lipocalin superfamily (Nagata et al., 1991; Hayaishi, 2000). Inf usion of $\mathrm{SeCl}_{4}$ or $\mathrm{PGD}_{2}$ alone and replacement of $\mathrm{PGD}_{2}$ after $\mathrm{SeCl}_{4}$ treatment established that $\mathrm{PGD}_{2}$ induces sleep and that inhibition of PGDS with $\mathrm{SeCl}_{4}$ induces increased amounts of an awake-like, aroused state in fetal sheep.

\section{MATERIALS AND METHODS}

\section{Animals}

Merino-Border Leicester crossbred ewes, which carry fetuses to $147 \mathrm{~d}$ gestation, were used in accordance with the rules of the Standing Committee on Ethics in Animal Experimentation of Monash University. The ewes were brought to the animal house and held together under artificially lit conditions on a $12 \mathrm{hr}$ light/dark cycle for at least $5 \mathrm{~d}$ before surgery $(n=13)$ or before they were killed to collect the fetal brain $(n=9)$.

Ex vivo studies: immunodetection of prostaglandin D synthase Fetal CSF and brain samples were collected at gestational ages of 90, 125, and $135 \mathrm{~d}(n=3$, each group). CSF was collected through a 23 gauge needle by puncturing the atlanto-occipital membrane immediately after the ewe had been killed and the fetus had been removed from the uterus. The fetal brain was then removed from the skull, the choroid plexus was removed from the lateral ventricles, and the remainder of the brain was divided into gross anatomical segments. The choroid plexus and brain samples were then frozen in liquid nitrogen. Samples of fetal liver and muscle were also collected for use as negative controls. At assay, the choroid plexus and selected segments of brain were weighed, pulverized on dry ice using an air hammer, and then homogenized in fresh buffer (in M: 0.1 phosphate, 0.32 sucrose, and 0.1 phenylmethylsulfonyl fluoride, $\mathrm{pH}$ 6) using an Ultra-Turrax (Janke and Kunkel GmbH, Staufen, Germany) homogenizer. The supernatant collected after centrifugation was subjected to SDS-PAGE electrophoresis on $12 \%$ acrylamide gel with a $4 \%$ stacking gel cast immediately before use. A lane containing protein standards between 14 and $97.4 \mathrm{kDa}$ was included on each gel. Samples prepared from whole cortexes of adult rats $(n=3)$ and samples of human CSF collected by spinal lumbar puncture (gift from Dr. Samantha Richardson, University of Melbourne, Parkville, Australia) were used as positive controls. The proteins were transferred from the gel to a nitrocellulose membrane by electrophoresis at $4^{\circ} \mathrm{C}$; complete transfer was confirmed subsequently by absence of Coomassie blue staining of the gel. The membrane was then treated with a protein blocking buffer $(0.1 \mathrm{M}$ phosphate, $0.05 \%$ Triton $\mathrm{X}-100$, and $3 \%$ nonfat powered milk), and incubated for $1 \mathrm{hr}$ with a 1:5000 dilution of a polyclonal antibody raised against $\beta$-trace protein purified from human CSF (gift from Professor M. Mader, University of Gottingen, Gottingen, Germany). After washing thoroughly in $0.1 \mathrm{M}$ phosphate buffer containing $0.05 \%$ Triton $\mathrm{X}-100$, the membrane was incubated for $1 \mathrm{hr}$ in secondary antibody (goat anti-rabbit; 1:10,000) conjugated to horseradish peroxidase, and the bound antibody complex was visualized by enhanced chemiluminescence (ECL kit; Amersham Biosciences, Little Chalfont, UK) and exposure to film (Biomax Light; Eastman Kodak, Rochester, NY). The level of $\beta$-trace protein on the membrane was quantitated using the Image Tool program from the University of Texas Health Science Center (San Antonio, TX).

\section{In utero studies}

Surgery. The animals fasted for $24 \mathrm{hr}$ before surgery at 125-126 d gestation for the long-term implantation of catheters and electrodes. The ewe was anesthetized using 1.5-2\% halothane in oxygen for the implantation of maternal and fetal carotid artery and jugular vein catheters and the placement of catheters into the midcervical region of the fetal trachea and the amniotic sac. Pairs of multistranded stainless-steel wires (Cooner
Wire Co., Chatsworth, CA) were sewn bilaterally into the nuchal muscles to measure EMG activity and subcutaneously at the margins of the orbit of one eye to measure the EOG (Clewlow et al., 1983). ECoG activity was recorded bilaterally from a pair of electrodes inserted through $1 \mathrm{~mm}$ diameter holes drilled through the skull over the parietal cortex. The bared ends of the insulated wires were inserted through the holes to rest on the dura, and the wires were then secured to the skull with cyanoacrylate glue. An indwelling cannula (inner diameter, $0.6 \mathrm{~mm}$; Intracath; Terumo Medical Corporation, Tokyo, Japan) was then inserted into one lateral ventricle using a 22 gauge needle, as described previously (Hirst et al., 2000). After the needle and cannula had been inserted into the ventricle, the needle was withdrawn and the outer end of the Intracath was attached to a port in the base of a hollow cap machined from Delrin, which was then secured to the skull with cyanoacrylate adhesive. [The use of this device to infuse ultra-small volumes into the fetal ventricle is described more fully below and by Hirst et al. (2000).] The internal space of the cap and cannula assembly was filled with sterile artificial CSF (aCSF) by means of inflow and outflow catheters sealed into the wall of the cap. The fetus was then given a subcutaneous injection $(2 \mathrm{ml})$ of a mixture of procaine penicillin $(200 \mathrm{mg} / \mathrm{ml})$ and dihydrostreptomycin $(250$ $\mathrm{mg} / \mathrm{ml}$ ) (Depomycin; Intervet Pty, Ltd., New South Wales, Australia). The uterus and membranes were repaired, and all catheters and wires were exteriorized from the abdomen through a $1 \mathrm{~cm}$ incision in the flank of the ewe. The abdominal incisions were then repaired and the ewe was allowed to recover. Experiments did not commence for at least $5 \mathrm{~d}$ after surgery.

Recordings. Tracheal pressure and carotid arterial pressures were recorded after electronic subtraction of amniotic pressure. Instantaneous heart rate was computed on-line from the pulse rate. The phasic changes of tracheal pressure were used as a measure of spontaneous fetal breathing movements. EOG and ECoG activities were amplified using wideband EEG pre-amplifiers (model 7P5B; Grass Instruments, West Warwick, RI) with frequency bandpass filters set at $1-15 \mathrm{~Hz}$ before being displayed directly on the polygraph. The EMG signal from the nuchal muscles was amplified, bandpass-filtered, and then integrated using a "leaky" integrator with the time constant set at $0.2 \mathrm{sec}$. All signals were recorded continuously for at least $24 \mathrm{hr}$ before the experiments began, using a paper chart speed of $5 \mathrm{~mm} / \mathrm{min}$.

Experimental procedures. The internal volume of the catheters and cap attached to the intraventricular cannula was first filled with an aCSF suitable for fetal sheep (Bissonnette et al., 1981). The two catheters were attached to glass syringes mounted onto a double-barrel infusion pump (model 70134; B. Braun Melsungen AG, Melsungen, Germany); fluid was simultaneously infused and withdrawn through the catheters and cap. The greater internal diameter of these catheters $(0.86 \mathrm{~mm})$ compared with that of the intraventricular cannula $(0.60 \mathrm{~mm})$, and the use of this push/pull perfusion system, ensured that the fluid passed through the cap and catheters and did not enter the ventricle through the cannula. Sterility was maintained by attaching a $0.20 \mu \mathrm{m}$ membrane filter (Minisart; Satorius AG, Gottingen, Germany) to the inflow syringe. Injection of known volumes of fluid into the ventricle was achieved by closing a stopcock on the outflow catheter for a known period of time, causing the fluid, which continued to be infused through the inflow catheter, to be forced through the cannula into the ventricle. Before commencement of infusion, both catheters and the cap were filled with the treatment solution. Infusion into the ventricle was done at a flow rate of $10 \mu \mathrm{l} / \mathrm{min}$ over $4 \mathrm{hr}$ so that the total volume delivered over this time was $2.4 \mathrm{ml}$. $\mathrm{SeCl}_{4}$ and $\mathrm{PGD}_{2}$ were made up in aCSF. The infusion rate was constant and used for all treatments; the quantity of $\mathrm{SeCl}_{4}$ or $\mathrm{PGD}_{2}$ delivered into the ventricle (picomoles per minute) was varied by changing the concentration of each substance in the infusate. At the end of each treatment the catheters and caps were refilled with fresh aCSF, leaving $\sim 10 \mu \mathrm{l}$ of the treatment solution in the dead-space of the ventricular cannula.

Polygraph records of breathing movements, blood pressure, heart rate, ECoG, nuchal EMG, and EOG activities were obtained for at least $4 \mathrm{hr}$ before and for $12 \mathrm{hr}$ after commencement of each treatment. Fetal arterial blood samples $(0.6 \mathrm{ml})$ were taken at hourly intervals for the measurement of blood gases, and the $\mathrm{pH}$ was corrected for the expected fetal body temperature of $38.5^{\circ} \mathrm{C}$ using an ABL5 (Radiometer, Copenhagen, Denmark) blood-gas analyzer. In the first part of the study, doses of $\mathrm{SeCl}_{4}$ or $\mathrm{PGD}_{2}$ between $25 \mathrm{pmol} / \mathrm{min}$ and $1 \mathrm{nmol} / \mathrm{min}$ were given to the fetuses to determine the effects on behavior. It was shown that 500 pmol of either $\mathrm{SeCl}_{4}$ or $\mathrm{PGD}_{2}$ produced maximal changes in fetal behavior, and in the final study, administration of $500 \mathrm{pmol} / \mathrm{min}$ of $\mathrm{SeCl}_{4}$ for $4 \mathrm{hr}$ was then followed immediately by a $4 \mathrm{hr}$ infusion of 500 
$\mathrm{pmol} / \mathrm{min}$ of $\mathrm{PGD}_{2}$ into the ventricle. To ensure that baseline conditions were achieved after each treatment, between 24 and $48 \mathrm{hr}$ elapsed between treatments in each fetus.

Postmortem. Immediately before postmortem examination at $142 \mathrm{~d}$ gestation, the lateral ventricle was infused with $100 \mu$ l of Indian Ink (Winsor \& Newton, London, UK), to verify correct insertion of the cannula into the lateral ventricle. The ewe was given an overdose of sodium pentobarbitone $(325 \mathrm{mg} / \mathrm{ml}$, i.v.; Lethobarb; Virbac, New South Wales, Australia) and the fetus was then immediately removed and weighed. In all the animals used for the study the cannula had passed through the cortex and the tip was observed to be in the lateral ventricle with no evidence of bleeding or tissue necrosis in the surrounding cortical tissue. Two fetuses in which the cannula had not entered the ventricle were excluded from the study.

Analysis of polygraph records. The entire $16 \mathrm{hr}$ record of each experiment was analyzed on a minute-to-minute basis. For each minute, the ECoG, EMG, EOG, and fetal breathing movements were coded and then used to determine which behavioral state was present. NREM sleep was defined as high-amplitude ECoG activity $(>100 \mu \mathrm{V})$ occurring simultaneously with sustained or tonic nuchal muscle EMG activity and the absence of EOG activity and breathing movements. REM sleep was considered to be present when the ECoG amplitude was of a low amplitude $(<100 \mu \mathrm{V})$ in the presence of EOG activity and breathing movements and with no tonic nuchal EMG activity. As originally defined (Szeto and Hinman, 1985) and used previously (Crossley et al., 1997; Nicol et al., 1998, 2001), arousal was identified as periods of nuchal EMG, EOG, and breathing movement activities in the presence of lowamplitude ECoG. Arterial pressure and heart rate were measured from the record at $10 \mathrm{~min}$ intervals and then averaged over 1 or $4 \mathrm{hr}$ epochs.

\section{Statistical analysis}

All data are presented as means \pm SEM. All data were checked for homogeneity of variance using Levene's test of equality of error variances. If the data were not normally distributed, they were transformed by square root or natural log. Data were analyzed by repeated-measures ANOVA in which the between-subject factor was dose $(0,25,100,500$, and $1000 \mathrm{pmol}$ of $\mathrm{SeCl}_{4}$ or $\mathrm{PGD}_{2}$ ) and the repeated variable (withinsubject factor) was time. When an interaction between factors was demonstrated, paired comparisons were made using the least significant difference test, and $p<0.05$ was considered to be statistically significant.

\section{RESULTS}

\section{Prostaglandin D synthase ( $\beta$-trace protein) in CSF}

Immunoreactive $\beta$-trace was detected in fetal CSF and adult human CSF (Fig. $1 A$ ) at an apparent molecular mass of $27 \mathrm{kDa}$, similar to that reported by others for this protein (Harrington et al., 1993). $\beta$-Trace protein was present in CSF taken from all fetuses at 125 and $135 \mathrm{~d}$ gestation but not in the samples from the three fetuses at $90 \mathrm{~d}$ gestation (Fig. $1 B, C$ ). There was no difference in expression of $\beta$-trace protein between fetuses at 125 and $135 \mathrm{~d}$ gestation. $\beta$-Trace protein was not detected in the fetal choroid plexus, liver, or skeletal muscle at any gestational age.

\section{Intraventricular infusions of $\mathrm{SeCl}_{4}$ and prostaglandin $\mathrm{D}_{2}$}

These experiments were performed in chronically catheterized and unanesthetized fetuses at 130-140 d gestation, in utero. In recordings made over $4 \mathrm{hr}$ before infusion of either $\mathrm{SeCl}_{4}$ or $\mathrm{PGD}_{2}$, all fetuses showed normal behavioral states, in which clearly differentiated episodes of high- and low-voltage ECoG activities were present (Fig. 2A). The mean duration of the individual low- and high-voltage ECoG episodes was $7.7 \pm 0.9$ and $4.8 \pm 0.8 \mathrm{~min}$, respectively, and the average incidences for the control period were $33.4 \pm 0.9$ and $26.6 \pm 0.9 \mathrm{~min} / \mathrm{hr}$. Of this, $25.1 \pm 0.9 \mathrm{~min} / \mathrm{hr}$ was occupied by the REM-like state (lowamplitude ECoG plus EOG activity and breathing movements) and $19.6 \pm 1.0$ min was occupied by the NREM-like state (highamplitude ECoG plus nuchal EMG activity). Intermittent periods of activity, defined as arousal because of the presence of low-
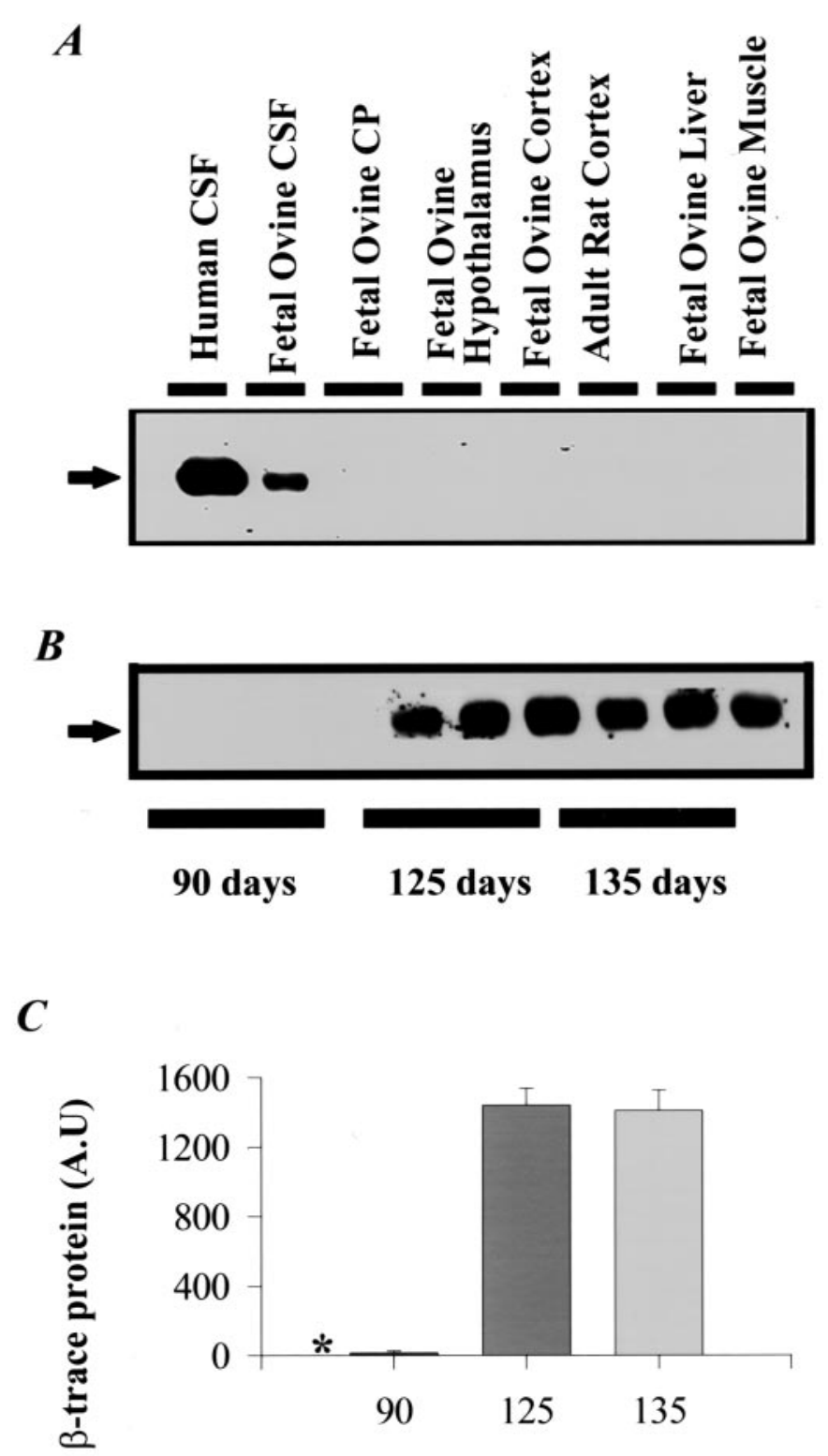

\section{Gestational Age (days)}

Figure 1. $A$, Western blot showing immunoreactive $\beta$-trace protein in adult human and fetal ovine CSF and its absence from fetal ovine choroid plexus $(C P)$ hypothalamus, liver and muscle, and adult rat cortex. The molecular mass marker $(27 \mathrm{kDa})$ shown by the arrow on the left was obtained from protein standards run on the same gel (data not shown). $B$, Western blot of immunoreactive $\beta$-trace protein in fetal ovine CSF at 90, 125 , and $135 \mathrm{~d}$ gestation $(n=3$ for each age). $\beta$-Trace protein was undetectable at $90 \mathrm{~d}$ gestation. The position of the $27 \mathrm{kDa}$ molecular mass marker is shown by the arrow on the left. $C$, Densitometric analysis of $\beta$-trace protein expression is shown in $B$. Results shown are means \pm SEM; the asterisk indicates a significant difference between the values at $90 \mathrm{~d}$ compared with those at 125 and $135 \mathrm{~d}$ gestation $(p<0.05)$.

voltage ECoG activity together with nuchal EMG and EOG activities, occurred from time to time at the transition between the two sleep states (Fig. $2 A$ ). The mean duration of the individual arousal-like episodes was $1.5 \pm 0.2 \mathrm{~min}$; the mean incidence of arousal activity was $3.3 \pm 0.3 \mathrm{~min} / \mathrm{hr}$. Arousal-like episodes were usually associated with a transient elevation of both blood 


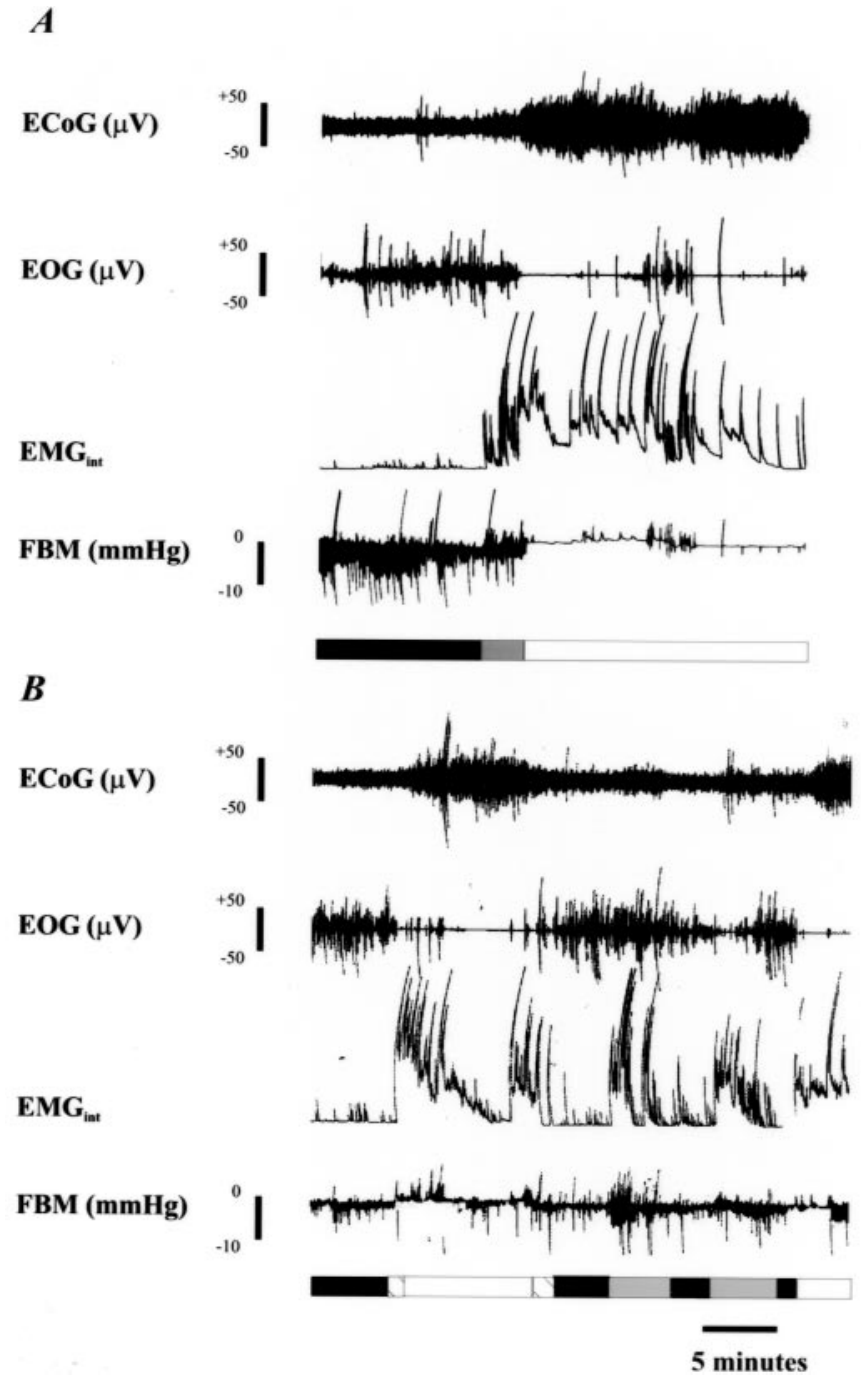

Figure 2. A, Polygraph recording during the pretreatment control period trace from a fetal sheep at $135 \mathrm{~d}$ gestation showing ECoG, EOG, integrated nuchal electromyogram $\left(E M G_{\text {int }}\right)$ and fetal breathing movement $(F B M)$ activities. REM sleep (black bar) was defined by the presence of FBM and EOG activity during low-amplitude ECoG activity. NREM sleep (open bar) was defined by the presence of varying but nearly continuous activity in the nuchal muscle during high-amplitude ECoG activity. Arousal (shaded bar) was identified by the presence of breathing movements, nuchal EMG, and EOG activities simultaneously with lowamplitude ECoG activity. $B$, Polygraph recording obtained from the same fetus shown in $A>9 \mathrm{hr}$ after the commencement of $\mathrm{SeCl}_{4}$ at 500 $\mathrm{pmol} / \mathrm{min}$ over $4 \mathrm{hr}$. Note the increase in the total amount of nuchal EMG and EOG activities and the increased incidence of the period defined as arousal (shaded bars). Periods that did not conform exactly to REM, NREM, or arousal behaviors are shown by the hatched bars at the beginning and end of the first NREM episode.

pressure and heart rate (data not shown). Because of either spurious artifact or record loss, $\sim 6 \mathrm{~min} / \mathrm{hr}$ could not be classified as REM, NREM, or arousal.

Infusion of $\mathrm{SeCl}_{4}$ into the lateral ventricle of the fetus increased the number and overall incidence of arousal-like episodes (Fig. 2B). This effect was evident when a dose of $500 \mathrm{pmol} / \mathrm{min}$ was infused for $4 \mathrm{hr}$, resulting in a significant increase in arousal activity at 9, 10, 11, and $12 \mathrm{hr}$ after starting the infusion (Fig. 3), compared with both the pretreatment values and the equivalent times during treatment with aCSF. Infusion of $\mathrm{SeCl}_{4}$ at 25

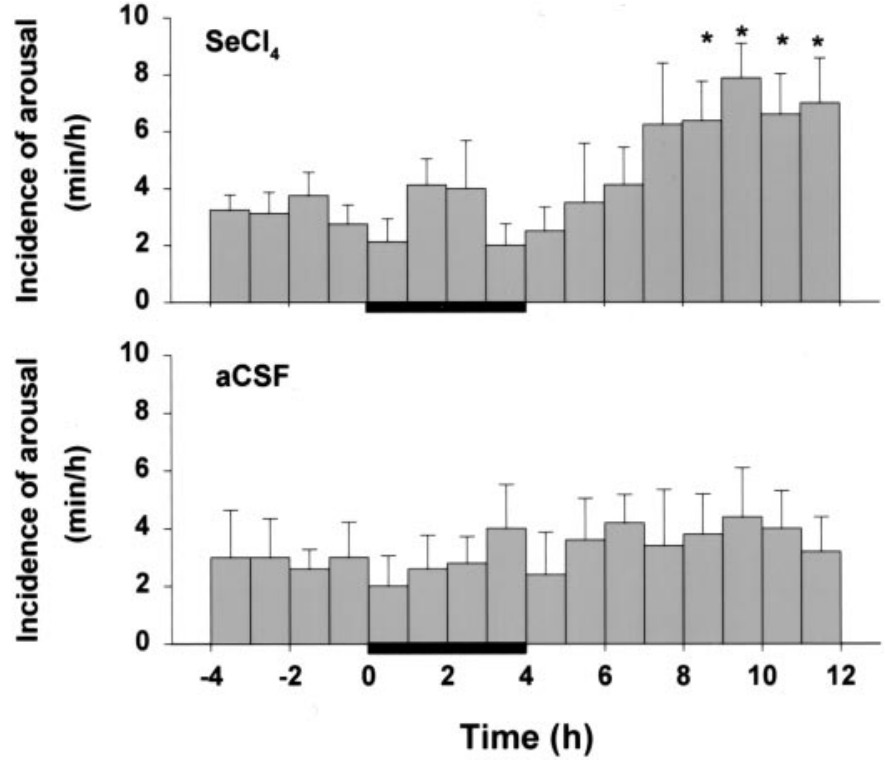

Figure 3. Effects of infusing aCSF $(n=5)$ or $\mathrm{SeCl}_{4}$ at $500 \mathrm{pmol} / \mathrm{min}$ $(n=4)$ on the hourly incidence (minutes per hour) of arousal-like activity. Infusions were administered into the left ventricle of fetuses at $130-140 \mathrm{~d}$ gestation at $10 \mu \mathrm{l} / \mathrm{min}$ for $4 \mathrm{hr}$ (solid bar). Administration of $\mathrm{SeCl}_{4}$ caused a significant increase $(p<0.05$, as shown by asterisks $)$ in the incidence of arousal compared with equivalent times for infusion of aCSF. Data shown are means \pm SEM.

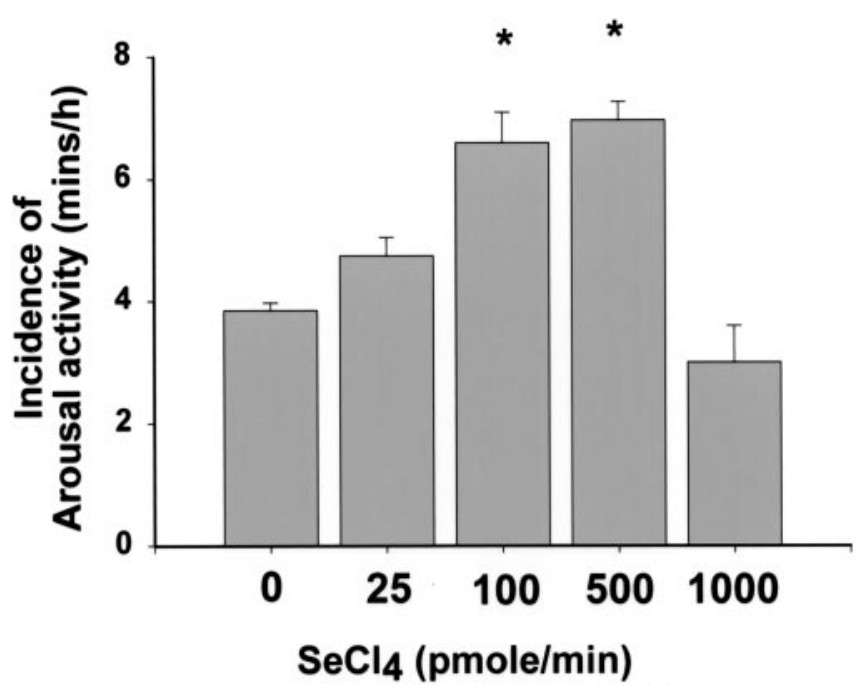

Figure 4. Effect of infusing $\mathrm{SeCl}_{4}$ at $25,100,500$, or $1000 \mathrm{pmol} / \mathrm{min}$ on the incidence (minutes per hour) of arousal behavior in fetal sheep. Zero dose was aCSF infused at $10 \mu \mathrm{l} / \mathrm{min}$ for $4 \mathrm{hr}$. Data shown are means \pm SEM.

$\mathrm{pmol} / \mathrm{min}$ briefly increased arousal at 8-9 hr after the start of treatment but did not produce sustained effects, whereas infusions of either 100 or $500 \mathrm{pmol} / \mathrm{min}$ increased the arousal incidence from $3.8 \pm 1 \mathrm{~min} / \mathrm{hr}$ to $6.6 \pm 0.5$ and $7.0 \pm 0.3 \mathrm{~min} / \mathrm{hr}$, respectively (Fig. 4). aCSF infused at $10 \mu \mathrm{l} / \mathrm{min}$ for $4 \mathrm{hr}$ did not significantly alter any of the indexes of fetal behavior. Inf usion of $\mathrm{SeCl}_{4}$ at $1 \mathrm{nmol} / \mathrm{min}$ over $4 \mathrm{hr}$ did not increase arousal activity (Fig. 4), but doses of 5 and $10 \mathrm{nmol} / \mathrm{min}$ produced seizure-like activity $(n=4$; data not shown). At the doses below $1 \mathrm{nmol} / \mathrm{min}$, $\mathrm{SeCl}_{4}$ had no effect on the overall incidences of low- and highvoltage ECoG activities. When arousal-like activity was in- 


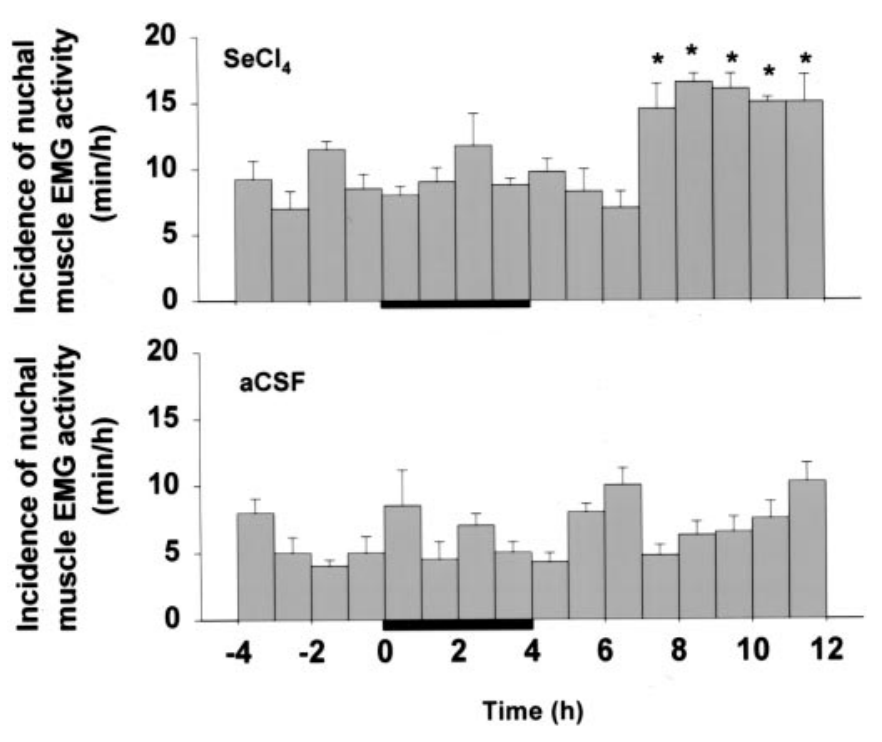

Figure 5. Effects of infusing aCSF $(n=5)$ or $\mathrm{SeCl}_{4}$ at $500 \mathrm{pmol} / \mathrm{min}$ $(n=4)$ on the hourly incidence of nuchal EMG activity in the presence of low-amplitude ECoG. Infusions were administered into the left cerebral ventricle of fetuses at 130-140 d gestation for $4 \mathrm{hr}$ (solid bar). Administration of $\mathrm{SeCl}_{4}$ caused a significant increase $(p<0.05$, as shown by asterisks) in the incidence of nuchal EMG activity in the presence of low-voltage activity compared with equivalent times for infusion of aCSF. Data shown are means \pm SEM.

creased, this was attributable primarily to an increase in the incidence of nuchal muscle EMG activity that occurred when low-voltage ECoG activity was present (Fig. 5). At doses of 25 and $100 \mathrm{pmol} / \mathrm{min}, \mathrm{SeCl}_{4}$ also increased the incidences of EOG activity and breathing movements (Fig. 6).

The intraventricular infusion of $\mathrm{PGD}_{2}$ alone had no significant effect on the incidences of low- and high-voltage ECoG activities, but the incidence of arousal was significantly decreased at doses of 500 and $1000 \mathrm{pmol} / \mathrm{min}$. As shown in Figure 7, when $\mathrm{PGD}_{2}$ was infused at $500 \mathrm{pmol} / \mathrm{min}$ the incidence of arousal-like behavior decreased from $3.8 \pm 0.5 \mathrm{~min} / \mathrm{hr}$ for the $4 \mathrm{hr}$ control period to 0.7 $\mathrm{min} / \mathrm{hr}$ at $6 \mathrm{hr}$ after the start of the infusion. This decrease in activity began during the $4 \mathrm{hr}$ infusion period, continued for $3 \mathrm{hr}$ after the end of the infusion, and was attributable to decreased incidences of nuchal EMG activity and breathing movements during low-voltage ECoG (data not shown).

Four fetuses were then treated with $\mathrm{SeCl}_{4}$ at $500 \mathrm{pmol} / \mathrm{min}$ for $4 \mathrm{hr}$, followed immediately by an intraventricular infusion of $\mathrm{PGD}_{2}$ at $500 \mathrm{pmol} / \mathrm{min}$ for $4 \mathrm{hr}$. As described above, at 500 $\mathrm{pmol} / \mathrm{min} \mathrm{SeCl}_{4}$ induced a significant increase in the incidence of arousal between 8 and $12 \mathrm{hr}$ after starting the infusion attributable to the significant increase in nuchal EMG activity (Fig. 8). This increase in arousal was abolished by an infusion of $\mathrm{PGD}_{2}$ at $500 \mathrm{pmol} / \mathrm{min}$ administered during the period 5-8 $\mathrm{hr}$ after the $\mathrm{SeCl}_{4}$ treatment was started. The decline in the incidence of arousal was attributable to a reduction in the incidence of nuchal EMG activity during the epochs of low-amplitude ECoG activity (Fig. 8). The combined infusion of $\mathrm{SeCl}_{4}$ and $\mathrm{PGD}_{2}$ did not significantly alter the incidences of low- and high-amplitude ECoG activities, or when analyzed separately, the overall incidences of EOG activity or breathing movements.

Infusion of aCSF over $4 \mathrm{hr}$ had no significant effect on the arousal-like behavior (Figs. 3 and 7) or nuchal muscle EMG activity exhibited by the fetuses (Fig. 5). Also, all separate and

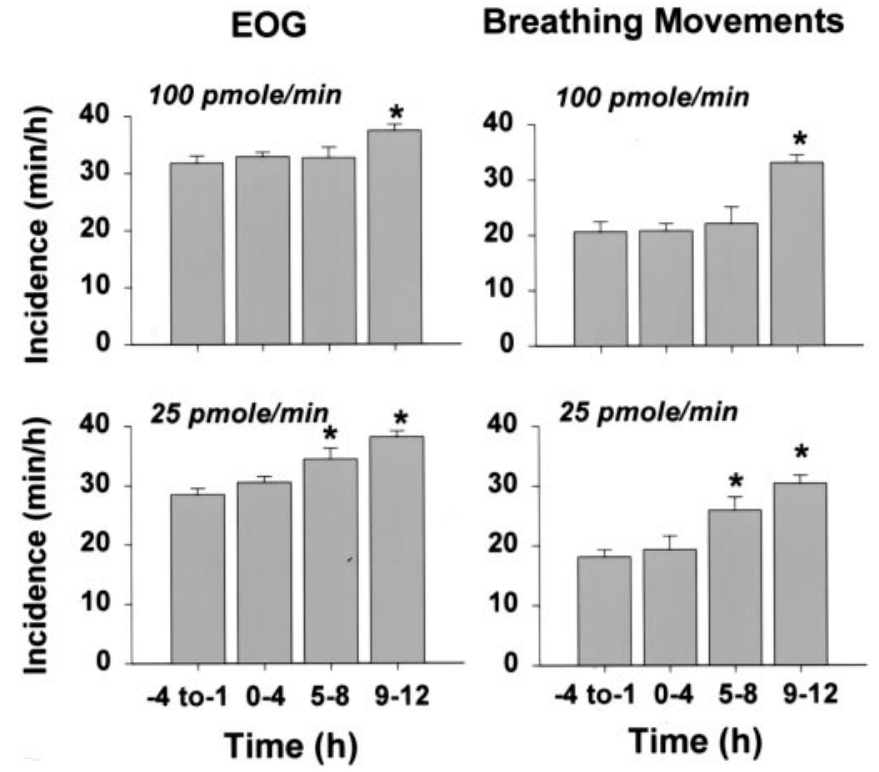

Figure 6. Effects of inf using $\mathrm{SeCl}_{4}$ for $4 \mathrm{hr}$ into the left cerebral ventricle of fetuses at 130-140 d gestation on the hourly incidence of EOG and breathing movements. Values were calculated by accumulating all activity over the $4 \mathrm{hr}$ epochs and then determining the mean incidence per hour. Administration of $\mathrm{SeCl}_{4}$ at $25(n=4)$ and $100(n=4) \mathrm{pmol} / \mathrm{min}$ caused a significant increase ( $p<0.05$, as shown by asterisks) in the incidence of nuchal EMG activity. Infusion of aCSF or the other doses of $\mathrm{SeCl}_{4}$ had no effects on these parameters. Data shown are means \pm SEM.

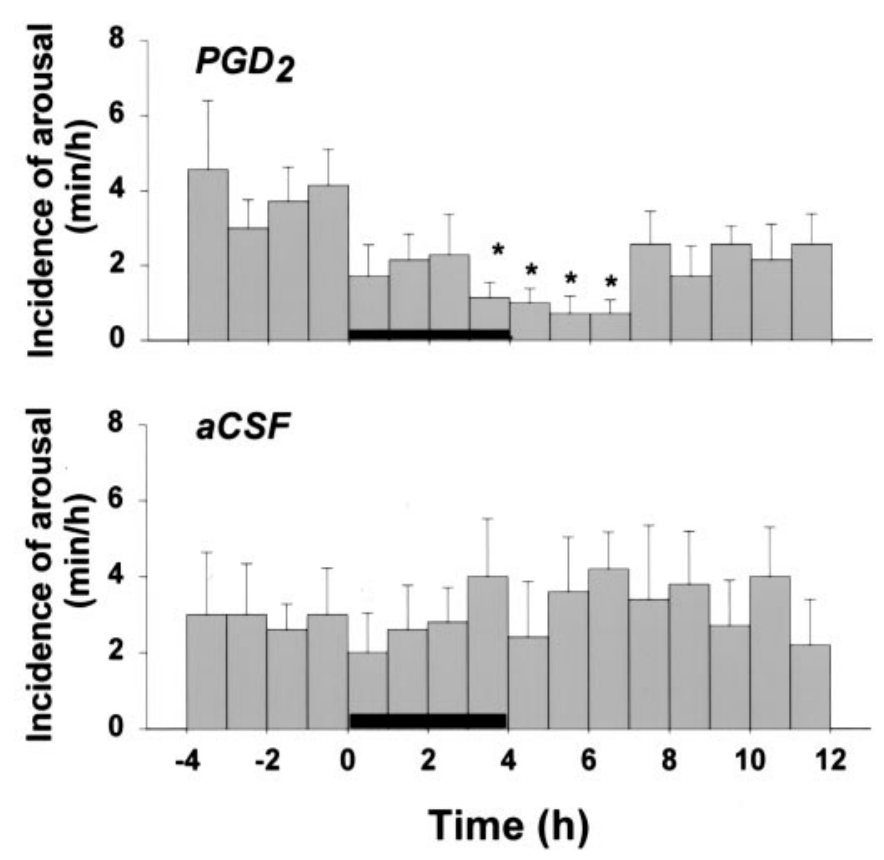

Figure 7. Effects of infusing aCSF $(n=5)$ or $\mathrm{PGD}_{2}$ at $500 \mathrm{pmol} / \mathrm{min}$ $(n=6)$ on the hourly incidence (minutes per hour) of arousal. Infusions were administered into the left ventricle of fetuses at 130-140 d gestation at $10 \mu \mathrm{l} / \mathrm{min}$ for $4 \mathrm{hr}$ (solid bar). $\mathrm{PGD}_{2}$ caused a significant decrease in the incidence of arousal ( $p<0.05$, as shown by asterisks) compared with both the control period within the treatment group and with equivalent times for infusion of aCSF. Data shown are means \pm SEM. 

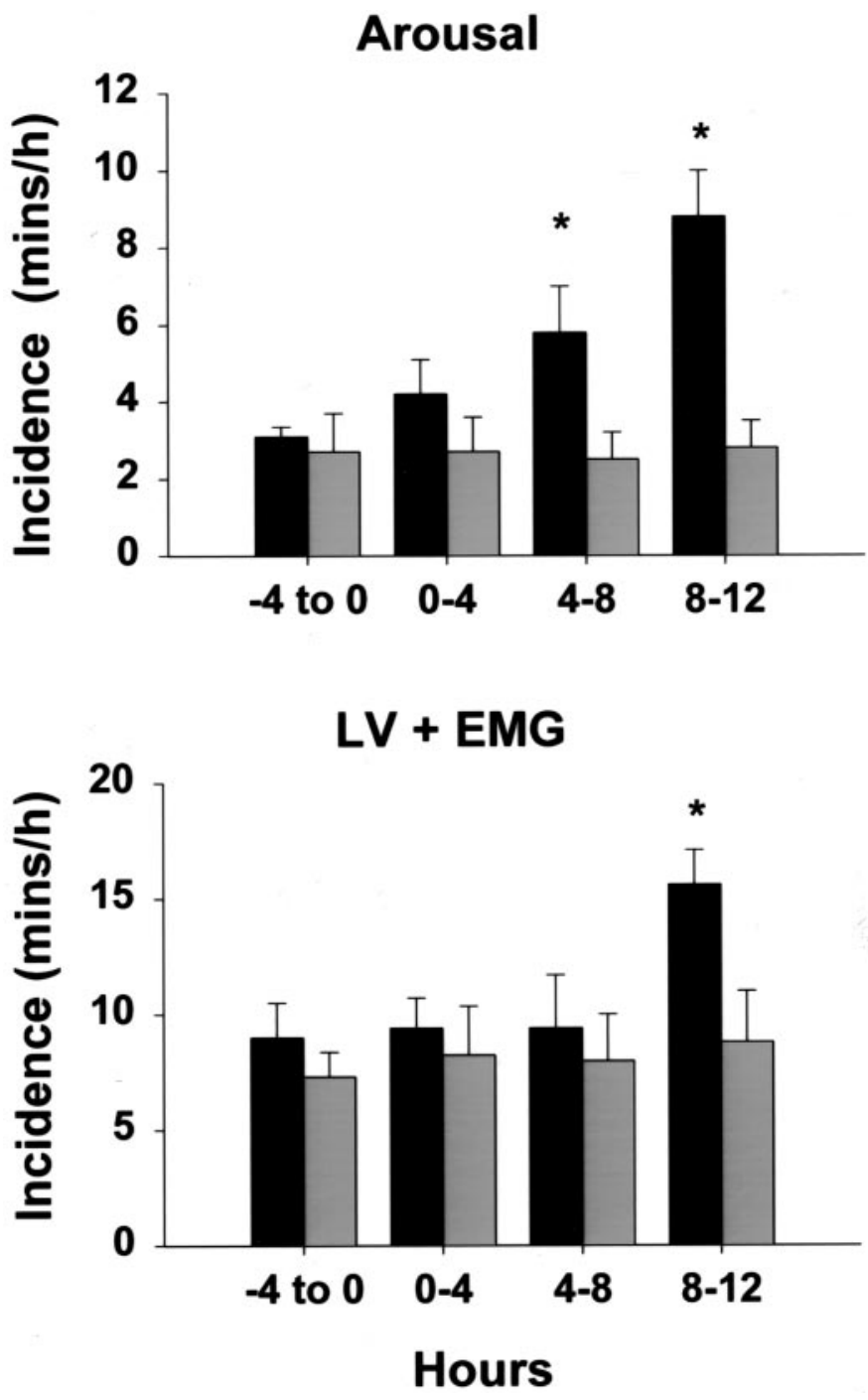

Figure 8. Effects of inf using $\mathrm{SeCl}_{4}$ alone at $500 \mathrm{pmol} / \mathrm{min}$ (solid bars) or the same dose of $\mathrm{SeCl}_{4}$ followed by a $4 \mathrm{hr}$ infusion of $\mathrm{PGD}_{2}$ at 500 $\mathrm{pmol} / \mathrm{min}$ (shaded bars). The increased incidences of arousal and nuchal muscle EMG activities produced by the $\mathrm{SeCl}_{4}$ treatments were abolished by the infusion of $\mathrm{PGD}_{2}$. Data shown are means \pm SEM ( $n=4$ fetuses) and demonstrate the incidence (minute per hour) of activity for consecutive $4 \mathrm{hr}$ epochs.

combined treatments with $\mathrm{SeCl}_{4}$ and $\mathrm{PGD}_{2}$ did not have any significant effects on the arterial blood gases, $\mathrm{pH}$, mean arterial pressure or heart rate (Tables 1 and 2). All of these parameters were in the normal range for fetal sheep at 130-140 d gestation.

\section{DISCUSSION}

We have shown that PGDS/ $\beta$-trace protein was undetectable in the CSF of fetal sheep at $90 \mathrm{~d}$ gestation but was clearly present by $125 \mathrm{~d}$ gestation and thereafter. The appearance of this particular protein in CSF in late gestation is counter to the general trend for proteins to decrease in fetal CSF (Dziegielewska et al., 1980), although the CSF protein concentration at $125 \mathrm{~d}$ gestation (50 $\mathrm{mg} / \mathrm{ml}$ ) is still approximately twice that in adult sheep. The appearance of PGDS/ $\beta$-trace protein in late gestation, at approximately the time that definite sleep states emerge, may be related to the onset of secretion of the protein from the choroid plexus and leptomeninges (Urade et al., 1995; Blodorn et al., 1996). The apparent absence of the protein from the fetal choroid plexus at any stage of development may be related to the low abundance of the protein in this tissue, because of its immediate secretion into CSF. Alternatively, the tertiary structure of the protein within the choroidal epithelial cells may differ from the secreted form. Similar results have been found in the human neonate, in which an antibody raised against the peptide sequence of human CSF $\beta$-trace did not recognize the protein in extracts of neonatal choroid plexus (Harrington et al., 1993).

An important finding of this study was that intraventricular infusion of $\mathrm{SeCl}_{4}$ caused a dose-dependent increase in the incidence of fetal CNS activities, similar to that which defines arousal in the adult animal. This increase in fetal arousal was abolished by the subsequent administration of $\mathrm{PGD}_{2}$ into the lateral ventricle. Inf usion of aCSF at the same rate $(10 \mu \mathrm{l} / \mathrm{min})$ over $4 \mathrm{hr}$ did not disrupt the ECoG, EOG, or nuchal muscle EMG activities, nor did it alter the patterns of activities from which the behavioral states of NREM and REM sleep and arousal are deduced. The production rate of CSF in late-gestation fetal sheep has been estimated to be $21.4 \mu \mathrm{l} / \mathrm{min}$ (Fossan et al., 1985) at $\sim 125 \mathrm{~d}$ gestation, and the total CSF volume is likely to be turned over four to five times per day, as for most adult mammals (Davson et al., 1987). Thus, it is likely that the $\mathrm{SeCl}_{4}$ would have been distributed throughout the CSF volume by the end of the $4 \mathrm{hr}$ infusion period. The delayed onset of the increase in arousal-like behavior is thus consistent with the inhibition of an enzyme system and the subsequent slow decline of $\mathrm{PGD}_{2}$ content in the brain and CSF. When $\mathrm{PGD}_{2}$ was administered, the suppression of arousal began during the time of the infusion, suggesting that it had access to a site(s) that influences sleep and arousal activity in the brain. This is consistent with the lipophilic nature of $\mathrm{PGD}_{2}$, which may enter the brain and reach the sites of action more rapidly compared with $\mathrm{SeCl}_{4}$. For $\mathrm{PGD}_{2}$, these sites are likely to be on the ventral surface of the rostral forebrain adjacent to the preoptic anterior hypothalamus (Matsumura et al., 1994; Scammell et al., 1998; Mizoguchi et al., 2001). The absence of any significant effects of the infusions on arterial pressure, heart rate, or blood gases also suggests that these treatments did not have significant nonspecific effects on brain functions.

The increase in the incidence of arousal behavior elicited by $\mathrm{SeCl}_{4}$ occurred because of an increase in the both the total amount of nuchal muscle EMG activity and the amount of nuchal EMG, EOG, and breathing activities present during the lowamplitude ECoG state. At $100 \mathrm{pmol} / \mathrm{min}, \mathrm{SeCl}_{4}$ did not alter the total amount of nuchal EMG activity present, but there was a redistribution of the amount of nuchal muscle activity, with a greater incidence occurring during low-amplitude ECoG, when normally there is little sustained or tonic activity in this muscle group. At $500 \mathrm{pmol} / \mathrm{min}, \mathrm{SeCl}_{4}$ increased the total amount of EMG activity present in addition to an increase during lowamplitude ECoG activity.

The increase in arousal after $\mathrm{SeCl}_{4}$ treatment implicates $\mathrm{PGD}_{2}$ in the tonic regulation of sleep in the fetal sheep. The leptomeninges and choroid plexus contain abundant PGDS, but the PGD receptor is highly expressed in arachnoid trabecular cells in the vicinity of the basal forebrain/anterior preoptic region (Mizoguchi et al., 2001). $\mathrm{PGD}_{2}$ appears to induce sleep by paracrine stimulation of adenosine release from these meningeal cells, which by exciting the adjacent sleep-active neurons in the VLPO leads in turn to GABAergic inhibition of the wake-promoting, histaminergic neurons in the tuberomammillary region of the posterior hypothalamus (for review, see Hayaishi, 2001). Block- 
Table 1. Fetal arterial blood gases, $\mathrm{pH}$, oxygen saturation, and hemoglobin concentration before (control) and at the end $(+4 \mathrm{hr})$ of intracerebroventricular infusion of aCSF or $\mathrm{SeCl}_{4}(500 \mathrm{pmol} / \mathrm{min})$, or at $+8 \mathrm{hr}$ after $\mathrm{SeCl}_{4}(500 \mathrm{pmol} / \mathrm{min})$ and then $\mathrm{PGD}_{2}(500 \mathrm{pmol} / \mathrm{min})$

\begin{tabular}{|c|c|c|c|c|c|c|c|c|c|c|}
\hline \multirow[b]{2}{*}{ Treatment } & \multicolumn{2}{|l|}{$\mathrm{pH}$} & \multicolumn{2}{|c|}{$\underline{\mathrm{P}_{\mathrm{CO}_{2}}(\mathrm{mmHg})}$} & \multicolumn{2}{|c|}{$\mathrm{P}_{\mathrm{O}_{2}}(\mathrm{mmHg})$} & \multicolumn{2}{|c|}{$\mathrm{O}_{2}$ saturation $(\%)$} & \multicolumn{2}{|c|}{ Hemoglobin $(\%)$} \\
\hline & Control & $+4 \mathrm{hr}$ & Control & $+4 \mathrm{hr}$ & Control & $+4 \mathrm{hr}$ & Control & $+4 \mathrm{hr}$ & Control & $+4 \mathrm{hr}$ \\
\hline $\mathrm{aCSF}$ & $7.37 \pm 0.010$ & $7.38 \pm 0.010$ & $40.0 \pm 3.0$ & $39.7 \pm 2.3$ & $23.4 \pm 2.3$ & $25.3 \pm 2.6$ & $64.5 \pm 6.9$ & $67.9 \pm 7.4$ & $8.8 \pm 0.5$ & $8.8 \pm 0.5$ \\
\hline $\mathrm{SeCl}_{4}$ & $7.40 \pm 0.003$ & $\begin{array}{l}7.40 \pm 0.003 \\
+8 \mathrm{hr}\end{array}$ & $42.2 \pm 0.9$ & $\begin{array}{l}41.1 \pm 2.7 \\
+8 \mathrm{hr}\end{array}$ & $26.4 \pm 1.3$ & $\begin{array}{l}26.9 \pm 0.9 \\
+8 \mathrm{hr}\end{array}$ & $73.9 \pm 2.3$ & $\begin{array}{l}75.1 \pm 2.5 \\
+8 \mathrm{hr}\end{array}$ & $10.5 \pm 0.8$ & $\begin{array}{l}9.0 \pm 1.2 \\
+8 \mathrm{hr}\end{array}$ \\
\hline $\mathrm{SeCl}_{4}+\mathrm{PGD}_{2}$ & $7.37 \pm 0.01$ & $7.37 \pm 0.01$ & $40.3 \pm 1.7$ & $40.8 \pm 1.5$ & $23.3 \pm 3.0$ & $26.0 \pm 1.4$ & $70.5 \pm 3.1$ & $69.8 \pm 1.1$ & $9.8 \pm 0.2$ & $9.9 \pm 0.3$ \\
\hline
\end{tabular}

Data shown are means \pm SEM.

Table 2. Fetal arterial blood pressure and heart rate before (control) and at the end $(+4 \mathrm{hr})$ of intracerebroventricular infusion of aCSF or $\mathrm{SeCl}_{4}(500 \mathrm{pmol} / \mathrm{min})$, or at $+8 \mathrm{hr}$ after $\mathrm{SeCl}_{4}(500 \mathrm{pmol} / \mathrm{min})$ and then $\mathrm{PGD}_{2}(500 \mathrm{pmol} / \mathrm{min})$

\begin{tabular}{|c|c|c|c|c|}
\hline \multirow[b]{2}{*}{ Treatment } & \multicolumn{2}{|c|}{$\begin{array}{l}\text { Mean arterial pressure } \\
(\mathrm{mmHg})\end{array}$} & \multicolumn{2}{|c|}{ Heart rate (beats/min) } \\
\hline & Control & $+4 \mathrm{hr}$ & Control & $+4 \mathrm{hr}$ \\
\hline $\mathrm{aCSF}$ & $48.2 \pm 7.5$ & $46.9 \pm 5.3$ & $163 \pm 4.8$ & $175 \pm 11.9$ \\
\hline $\mathrm{SeCl}_{4}$ & $43.9 \pm 5.1$ & $\begin{array}{l}46.3 \pm 4.9 \\
+8 \mathrm{hr}\end{array}$ & $175 \pm 12.8$ & $\begin{array}{l}174 \pm 7.0 \\
+8 \mathrm{hr}\end{array}$ \\
\hline $\mathrm{SeCl}_{4}+\mathrm{PGD}_{2}$ & $39.9 \pm 6.1$ & $38.2 \pm 6.0$ & $157 \pm 7.5$ & $158 \pm 2.4$ \\
\hline
\end{tabular}

Data shown are means \pm SEM.

ade of adenosine type $2 \mathrm{~A}_{2}$ receptors in fetal sheep leads to increased high-voltage ECoG activity and NREM-like sleep in fetal sheep (Koos et al., 2001). In addition, we have shown that neurosteroid modulation of $\mathrm{GABA}_{\mathrm{A}}$ receptor activity leads to alterations of the fetal sleep states and arousal-like behavior (Crossley et al., 1997; Nicol et al., 1998, 2001). Thus, the neurotransmitters and neuromodulators of the putative hypothalamic sleep/wake system appear to have developed in the sheep brain by late gestation.

Another reason for the effect of $\mathrm{SeCl}_{4}$ on fetal behavior might be that reduction of PGDS activity permitted increased production of $\mathrm{PGE}_{2}$ from the common arachidonate precursor $\mathrm{PGH}_{2}$. In adult rats it has been proposed that $\mathrm{PGE}_{2}$ acts directly on posterior hypothalamic neurons to induce wakefulness (Matsumura et al., 1988). However, it should be noted that systemic infusions of $\mathrm{PGE}_{2}$ or the PG synthase inhibitors indomethacin or meclofenamate do not alter sleep states or arousal in fetal sheep (Kitterman, 1987). It is possible that changes in the ratio of $\mathrm{PGD}_{2}$ and $\mathrm{PGE}_{2}$ concentrations in the fetal brain determine the propensity for sleep and wakefulness.

Whether the increases in nuchal EMG, EOG, and breathing activities during low-amplitude ECoG represent true arousal in the fetus must also be considered. Consistent with previous studies, transient increases in fetal blood pressure and heart rate have been observed during episodes identified as arousal (Szeto, 1992), and similar cardiovascular and autonomic changes occur in the newborn infant on arousal from sleep (Read et al., 1998). In a recent study we showed that evoked somatosensory responses were increased in amplitude after treating fetal sheep with the $5 \alpha$-reductase inhibitor finasteride, a treatment that also increased the incidence of fetal arousal (Nicol et al., 2001). These observations are consistent with the episodes identified as fetal arousal as also being periods during which there is increased cortical excitability. Nevertheless, it is also of interest that the arousal-like episodes are brief, even after intracerebroventricular infusion of
$\mathrm{SeCl}_{4}$, suggesting that powerful sleep-promoting mechanisms remain active in the fetal sheep until the time of birth. The results of this study suggest that a $\mathrm{PGD}_{2}$ mechanism contributes to the suppression of wakefulness in the fetus, but it is not the sole mechanism that maintains the sleep that accounts for most of the behavioral state in fetal life.

Other proposed functions of PGDS/ $\beta$-trace protein may be important. It has been identified as a member of the lipocalin superfamily in the basis of conserved tertiary structure (Nagata et al., 1991), making it apparent that this protein may be involved in the transmembrane transport of small lipophilic molecules. In adults, $\beta$-trace protein is constitutively expressed at other bloodtissue boundaries, including the retina (Beuckmann et al., 1996; Gerashchenko et al., 1998) and testis (Tokugawa et al., 1998). Thus, this lipocalin-like protein may be involved in the transport of essential substrates into tissues that possess a microvasculature with barrier properties.

In summary, we have shown that inhibition of PGDS by $\mathrm{SeCl}_{4}$ markedly increases the incidence of arousal-like behavior in lategestation fetal sheep. This arousal-like activity was suppressed by $\mathrm{PGD}_{2} ; \mathrm{PGD}_{2}$ replacement also prevented the actions of $\mathrm{SeCl}_{4}$. These findings suggest that the activity of PGDS and production of $\mathrm{PGD}_{2}$ in the fetal brain has a role in suppressing wakefulness and maintaining sleep in utero.

\section{REFERENCES}

Adamson SL, Richardson BS, Homan J (1987) Initiation of pulmonary gas exchange by fetal sheep in utero. J Appl Physiol 62:989-998.

Beuckmann CT, Gordon WC, Kanaoka Y, Eguchi N, Marcheselli VL, Gerashchenko DY, Urade Y, Hayaishi O, Bazan NG (1996) Lipocalin-type prostaglandin D synthase $(\beta$-trace) is located in pigment epithelial cells of rat retina and accumulates within interphotoreceptor matrix. J Neurosci 16:6119-6124.

Bissonnette JM, Hohimer AR, Richardson BS (1981) Ventriculocisternal cerebrospinal perfusion in unanesthetized fetal lambs. J Appl Physiol 50:880-883.

Blodorn B, Mader M, Urade Y, Hayaishi O, Felgenhauer K, Bruck W (1996) Choroid plexus: the major site of mRNA expression for the $\beta$-trace protein (prostaglandin D synthase) in the human brain. Neurosci Lett 209:117-120.

Clewlow F, Dawes GS, Johnston BM, Walker DW (1983) Changes in fetal breathing, electrocortical and muscle activity in unanaesthetised fetal lambs with age. J Physiol (Lond) 341:463-476.

Crossley K, Nicol MB, Hirst JJ, Walker DW, Thorburn GD (1997) Suppression of arousal by progesterone in fetal sheep. Reprod Fertil Dev 9:767-773.

Davson H, Welch K, Segal MB (1987) The physiology and pathophysiology of the cerebrospinal fluid. London: Churchill Livingstone.

Dawes GS, Fox HE, Leduc BM, Liggins GC, Richards RT (1972) Respiratory movements and rapid eye movement sleep in the foetal lamb. J Physiol (Lond) 220:119-143.

Dawes GS, Gardner WN, Johnston BM, Walker DW (1983) Breathing in fetal lambs: effect of brainstem and midbrain transection. J Physiol (Lond) 335:535-555.

Dziegielewska KM, Evans CA, Fossan G, Lorscheider FL, Malinowska DH, Mollgard K, Reynolds ML, Saunders NR, Wilkinson S (1980) Proteins in cerebrospinal fluid and plasma of fetal sheep during development. J Physiol (Lond) 300:441-455.

Fossan G, Cavanagh ME, Evans CA, Malinowska DH, Mollgard K, 
Reynolds ML, Saunders NR (1985) CSF-brain permeability in the immature fetus: a CSF-brain barrier. Brain Res 350:113-124.

Gerashchenko DY, Beuckmann CT, Marcheselli VL, Gordon WC, Kanaoka Y, Eguchi N, Urade Y, Hayaishi O, Bazan NG (1998) Localization of lipocalin-type prostaglandin $D$ synthase $(\beta$-trace) in iris, ciliary body, and eye fluids. Invest Ophthalmol Vis Sci 39:198-203.

Harrington MG, Aebersold R, Martin BM, Merril CR, Hood L (1993) Identification of a brain-specific human cerebrospinal fluid glycoprotein, $\beta$-trace protein. Appl Theor Electrophor 3:229-234.

Hayaishi O (2000) Molecular mechanisms of sleep-wake regulation: a role of prostaglandin $\mathrm{D}_{2}$. Philos Trans $\mathrm{R}$ Soc Lond $\mathrm{B}$ Biol Sci 355:275-280.

Hayaishi O, Matsumura H, Urade Y (1993) Prostaglandin D synthase is the key enzyme in the promotion of physiological sleep. J Lipid Mediat $6: 429-431$.

Hirst JJ, Egodagamage KC, Walker DW (2000) Effect of a neuroactive steroid infused into the cerebral ventricles of fetal sheep in utero using small infusion volumes. J Neurosci Methods 97:37-44.

Hoffman A, Conradt HS, Gross G, Nimtz M, Lottspeich F, Wurster U (1993) Purification and chemical characterisation of $\beta$-trace protein from human cerebrospinal fluid: its identification as prostaglandin D synthase. J Neurochem 61:451-456.

Hoffman A, Gath U, Gross G, Lauber J, Getzlaff R, Hellwig S, Galla HJ, Conradt HS (1996) Constitutive secretion of $\beta$-trace protein by cultured porcine choroid plexus epithelial cells: elucidation of its complete amino acid and cDNA sequences. J Cell Physiol 169:235-241.

Islam F, Watanabe Y, Morii H, Hayaishi O (1991) Inhibition of rat brain PGD synthase by inorganic selenocompounds. Arch Biochem Biophys 289:161-166

Kitterman JA (1987) Arachidonic acid metabolites and control of breathing in the fetus and newborn. Semin Perinatol 11:43-52.

Koos BJ, Maeda T, Jan C (2001) Adenosine $A_{1}$ and $A_{2 A}$ receptors modulate sleep state and breathing in fetal sheep. J Appl Physiol 91:343-350

Matsumura H, Goh Y, Ueno R, Sakai T, Hayaishi O (1988) Awaking effect of $\mathrm{PGE}_{2}$ injected into the preoptic area of rats. Brain Res 444:265-272.

Matsumura H, Takahata R, Hayaishi O (1991) Inhibition of sleep in rats by inorganic selenium compounds, inhibitors of prostaglandin D synthase. Proc Natl Acad Sci USA 88:9046-9050.

Matsumura H, Nakajima T, Osaka T, Satoh S, Kawase K, Kubo E, Kantha S, Kasahara K, Hayaishi O (1994) Prostaglandin $\mathrm{D}_{2}$-sensitive, sleep promoting zone defined in the ventral surface of the rostral forebrain. Proc Natl Acad Sci USA 91:11998-12002.

Mizoguchi A, Eguchi N, Kimura K, Kiyohara Y, Qu W-M, Huang Z-L, Mochizuki T, Lazarus M, Kobayashi T, Kaneko T, Narimiya S, Urade Y, Hayaishi O (2001) Dominant localization of prostaglandin D receptors on arachnoid trabecular cells in mouse basal forebrain and their involvement in the regulation of non-rapid eye movement sleep. Proc Natl Acad Sci USA 98:11674-11679.

Nagata A, Suzuki Y, Igarashi M, Eguchi N, Toh H, Urade Y, Hayaishi O
(1991) Human brain prostaglandin D synthase has been evolutionarily differentiated from lipophilic-ligand carrier proteins. Proc Natl Acad Sci USA 88:4020-4024.

Nicol MB, Hirst JJ, Walker DW (1998) Effect of pregnane steroids on electrocortical activity and somatosensory evoked potentials in fetal sheep. Neurosci Lett 253:111-114.

Nicol MB, Hirst JJ, Walker DW (2001) Effect of finasteride on behavioural arousal and somatosensory evoked potentials in fetal sheep. Neurosci Lett 306:13-16.

Ohe Y, Ishikawa K, Itoh Z, Tatemoto K (1996) Cultured leptomeninge cells secrete cerebrospinal fluid proteins. J Neurochem 67:964-971.

Pandley HP, Ram A, Matsumura H, Hayaishi O (1995) Concentrations of prostaglandin $\mathrm{D}_{2}$ in cerebrospinal fluid exhibits a circadian alteration in conscious rats. Biochem Mol Biol Int 37:431-437.

Ram A, Pandley HP, Matsumura H, Kasahara-Orita K, Nakajima T, Takahata R, Satoh S, Terao A, Hayaishi O (1997) CSF levels of prostaglandins, especially the level of prostaglandin $\mathrm{D}_{2}$, are correlated with increasing propensity towards sleep in rats. Brain Res 751:81-89.

Read PA, Horne RSC, Cranage SM, Walker AM, Walker DW, Adamson TM (1998) Dynamic changes in arousal threshold during sleep in the human infant. Pediatr Res 43:697-703.

Ruckebusch Y, Gaujoux M, Eghbali B (1977) Sleep cycles and kinesis in the foetal lamb. Electroencephalogr Clin Neurophysiol 42:226-237.

Scammell T, Gerashchenko D, Urade Y, Onoe H, Saper C, Hayaishi O (1998) Activation of ventrolateral preoptic neurons by the somnogen prostaglandin $\mathrm{D}_{2}$. Proc Natl Acad Sci USA 95:7754-7759.

Sherin JE, Shiromani PJ, McCarley RW, Saper CB (1996) Activation of ventrolateral preoptic neurons during sleep. Science 271:216-219.

Szeto HH (1992) Behavioural states and their ontogeny: animal studies. Semin Perinatol 16:211-216.

Szeto HH, Hinman DJ (1985) Prenatal development of sleep-wake patterns in sheep. Sleep 8:347-355.

Tokugawa Y, Kunishige I, Kubota Y, Shimoya K, Nobunaga T, Kimura T, Saji F, Murata Y, Eguchi N, Oda H, Urade Y, Hayaishi O (1998) Lipocalin-type prostaglandin D synthase in human male reproductive organs and seminal plasma. Biol Reprod 58:600-607.

Urade O, Hayaishi O (1999) Prostaglandin $D_{2}$ and sleep regulation. Biochim Biophys Acta 1436:606-615.

Urade Y, Kitahama K, Ohishi H, Kaneko T, Mizuno N, Hayaishi O (1993) Dominant expression of mRNA for prostaglandin D synthase in leptomeninges, choroid plexus, and oligodendrocytes of the adult rat brain. Proc Natl Acad Sci USA 90:9070-9074.

Urade Y, Eguchi N, Kantha SS, Kanaoka Y, Beuckmann C, Watanabe K, Hayaishi O, Kitahama K, Ohishi H, Kaneko T, Mizuno N, Mader M, Murphy C (1995) Prostaglandin D synthase, the key enzyme of sleep regulation, is mainly localised in the leptomeninges and choroid plexus, and is secreted into cerebrospinal fluid. Sleep Res 24A:107.

Watanabe K, Urade Y, Mader M, Murphy C, Hayaishi O (1994) Identification of $\beta$-trace as prostaglandin D synthase. Biochem Biophys Res Commun 203:1110-1116. 